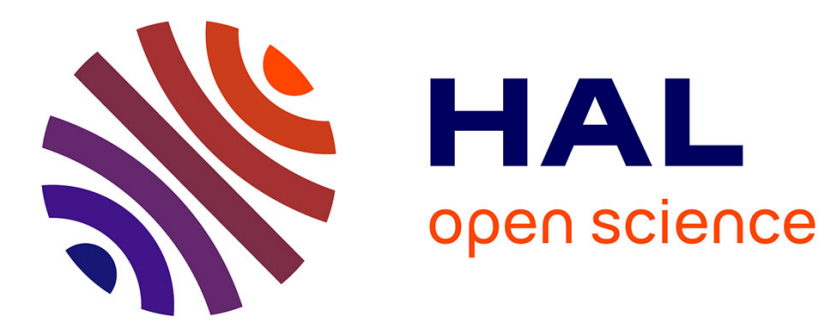

\title{
Interannual variability and future projection of summertime ocean wave heights in the western North Pacific
}

\author{
W. Sasaki, T. Hibiya, T. Kayahara
}

\section{- To cite this version:}

W. Sasaki, T. Hibiya, T. Kayahara. Interannual variability and future projection of summertime ocean wave heights in the western North Pacific. Ocean Science Discussions, 2006, 3 (5), pp.1637-1651. hal00298429

\section{HAL Id: hal-00298429 \\ https://hal.science/hal-00298429}

Submitted on 6 Oct 2006

HAL is a multi-disciplinary open access archive for the deposit and dissemination of scientific research documents, whether they are published or not. The documents may come from teaching and research institutions in France or abroad, or from public or private research centers.
L'archive ouverte pluridisciplinaire HAL, est destinée au dépôt et à la diffusion de documents scientifiques de niveau recherche, publiés ou non, émanant des établissements d'enseignement et de recherche français ou étrangers, des laboratoires publics ou privés. 
Wave height projection in the WNP

W. Sasaki et al.

\section{Interannual variability and future projection of summertime ocean wave heights in the western North Pacific}

W. Sasaki ${ }^{1}$, T. Hibiya ${ }^{2}$, and T. Kayahara ${ }^{1}$

${ }^{1}$ Storm, Flood and Landslide Research Department, National Research Institute for Earth Science and Disaster Prevention, Tsukuba, Japan

${ }^{2}$ Department of Earth and Planetary Science, Graduate School of Science, University of Tokyo, Tokyo, Japan

Received: 19 September 2006 - Accepted: 4 October 2006 - Published: 6 October 2006 Correspondence to: W. Sasaki (wsasaki@ bosai.go.jp)

Title Page
Abstract

Conclusions

Tables

14

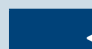

4

Back Introduction

References

Figures

$\Delta$

$\triangleright$

Close

Full Screen / Esc

Printer-friendly Version

Interactive Discussion 


\section{Abstract}

A 70-yr (from 1985-1995 to 2055-2065) change of decadal mean summertime extreme significant wave heights $(\mathrm{SWH})$ in the western North Pacific under $\mathrm{CO}_{2}$-induced global warming condition is projected. For this purpose, possible atmospheric fields 5 under future global warming are derived from 10-yr time-slice experiments using a T106 AGCM. The future changes of SWH are assessed by an empirical approach, where possible changes of SWH are estimated using a linear regression model which shows an empirical relationship between $\mathrm{SWH}$ anomalies and an eastward shift of the monsoon trough. It is projected that SWH increases by up to $\sim 0.4 \mathrm{~m}$ over a wide area of the western North Pacific .

\section{Introduction}

Some of the state-of-the-art coupled climate models predict increase of the intensity of tropical cyclone (TC) and decrease of the frequency of TC under $\mathrm{CO}_{2}$-induced global warming (Krishnamurti et al., 1998). Since the changes of TC intensity as well

\section{ocean wave heights in the area where the TC frequently develops.}

Future changes of ocean wave heights were first projected by the Waves and Storms in the North Atlantic (WASA) Group (WASA, 1998). They carried out 5-yr time-slice experiments for the North Atlantic to present a statistical projection of intramonthly quantiles of ocean wave heights at Brent and near Ekofisk. They also presented a dynamical projection of changes of ocean wave heights by driving the third-generation wave model using surface wind fields derived from the time-slice experiments. Wang et al. (2004) projected wave climate changes in the North Atlantic for the 21st century using sea level pressure fields derived from a global climate model under three different forcing scenarios. Recently, this method was applied to project seasonal averages and extremes of ocean wave heights all over the world with three global climate models
OSD

3, 1637-1651, 2006

\section{Wave height projection in the WNP}

W. Sasaki et al.

Title Page

Abstract Introduction

Conclusions References

Tables Figures

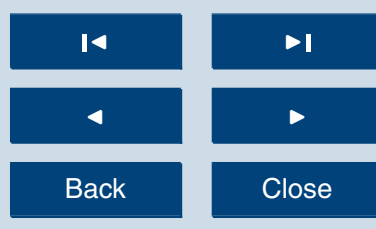

Full Screen / Esc

Printer-friendly Version

Interactive Discussion 
for three forcing-scenarios (Wang and Swail, 2006). Moreover, they discussed the uncertainties in the projections of wave heights in terms of the differences among the three climate models as well as three forcing-scenarios.

In this paper, we present an empirical projection of a 70-yr (from 1985-1995 to 5 2055-2065) change of 10-yr mean summertime extreme significant wave heights in the western North Pacific (WNP) under $\mathrm{CO}_{2}$-induced global warming condition. First, possible atmospheric fields under future global warming are derived from the time-slice experiments. Next, thus derived information is incorporated into the linear regression model which empirically relates the atmospheric fields to interannual variability of SWH.

\section{Data and time-slice experiments}

\subsection{Reanalysis data and employed procedures}

We use significant wave heights $(\mathrm{SWH})$, surface wind $(\mathrm{SW})$, and sea level pressure (SLP) fields covering the world ocean on a $2.5^{\circ} \times 2.5^{\circ}$ grid at $6-\mathrm{h}$ intervals for September 1957-August 2002 obtained from the ERA-40 reanalysis, namely, a 40-yr reanalysis of the atmospheric and oceanic fields developed at the European Centre for MediumRange Weather Forecasts. We also use monthly mean sea surface temperature (SST) fields obtained from the Extended Reconstructed Sea Surface Temperature (ERSST) (Smith and Reynolds, 2004). From these datasets, we can obtain 3-month (JuneAugust) averaged maps of the monthly 90th percentile of $\mathrm{SWH}\left(\mathrm{H}_{90}\right)$, SW, SLP, and SST for each year. However, we exclude $\mathrm{H}_{90}$ in 1992 from the datasets since the ERA40 wave reanalysis has inhomogeneity during December 1991-May 1993 because of the assimilation of faulty ERS-1 Fast Delivery Product (Bauer and Staabs, 1998).

To obtain a regression model which relates dominant interannual variability of $\mathrm{H}_{90}$ to monthly mean atmospheric fields, we apply an Empirical Orthogonal Function (EOF) analysis to the above obtained 3-month averaged $\mathrm{H}_{90}$ field for the region $0^{\circ} \mathrm{N}-40^{\circ} \mathrm{N}$, $100^{\circ} \mathrm{E}-180^{\circ}$ based on the covariance matrix. The first EOF of $\mathrm{H}_{90}$ accounts for $51.0 \%$

OSD

3, 1637-1651, 2006

\section{Wave height projection in the WNP}

W. Sasaki et al.

Title Page

Abstract Introduction

Conclusions References

Tables Figures

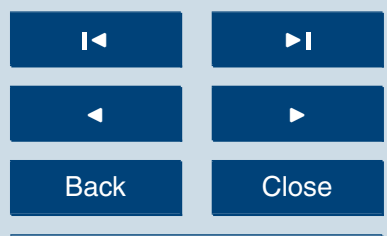

Full Screen / Esc

Printer-friendly Version

Interactive Discussion 
of the total variance within this region. The explained variance is $13.0 \%$ for the second mode and $5.5 \%$ for the third mode, both much smaller than that of the first mode, so that we focus only on the first EOF mode hereafter. To identify the $\mathrm{H}_{90}$, SST, and atmospheric anomalies associated with the first EOF mode of $\mathrm{H}_{90}$ in the WNP, we 5 illustrate a map of linear regression coefficients between the principal component for the first EOF mode (PC1) and each of $\mathrm{H}_{90}$, SST, SW, and SLP (Fig. 1).

For tropical cyclones (TCs), we use the TC best-track data issued by the Regional Specialized Meteorological Center (RSMC) Tokyo Typhoon Center as well as the TC best-track data from the U.S. Joint Typhoon Warning Center (JTWC).

$10 \quad 2.2$ Time-slice experiments

Present-day and future atmospheric fields are simulated by a pair of time-slice experiments (control run as well as $2 \times \mathrm{CO}_{2}$ run) using an atmospheric general circulation model (AGCM). The employed AGCM is the global spectral model which has been used as the forecast model in the Japan Meteorological Agency (Sugi et al., 1990) 5 and is the atmospheric component of a coupled ocean-atmosphere general circulation model (CGCM) developed at the National Research Institute for Earth Science and Disaster Prevention (Matsuura et al., 1999; lizuka et al., 2003). In this study, the AGCM is configured with the horizontal spectral truncation of T106, and 21 vertical levels.

In the control run where the carbon dioxide $\left(\mathrm{CO}_{2}\right)$ concentration is fixed at $350 \mathrm{ppm}$, 20 we integrate the AGCM for 11 years to reproduce the equilibrium response to climatological SST fields for 1985-1995 derived from the ERSST. In the $2 \times \mathrm{CO}_{2}$ run where the $\mathrm{CO}_{2}$ concentration is fixed at $700 \mathrm{ppm}$, we use climatological SST fields derived from the Greenhouse gases Plus Sulfates (GPS) experiments with a coarse-resolution (R30) CGCM developed at the Geophysical Fluid Dynamics Laboratory (Delworth et 25 al., 2002). In the GPS experiments, $\mathrm{CO}_{2}$ concentration is assumed to increase at a rate following the IS92a scenario until 1990, and at a rate $1 \%$ per year thereafter. A striking feature of the SST fields from the GPS experiments is that the Pacific SST fields exhibits an EI Niño Southern Oscillation (ENSO)-like pattern. To obtain the pos-
OSD

3, 1637-1651, 2006

\section{Wave height projection in the WNP}

W. Sasaki et al.

Title Page

Abstract Introduction

Conclusions References

Tables Figures

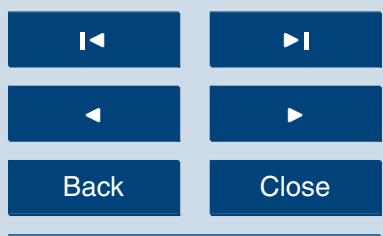

Full Screen / Esc

Printer-friendly Version

Interactive Discussion 
sible SST field under $\mathrm{CO}_{2}$-induced future global warming, the difference between SST for 2055-2065 and that for 1985-1995 is added to the observed SST; for the resulting SST field, the AGCM is integrated for 11 years.

We now examine TC activity in the control run using two different cumulus convec5 tion schemes, namely, the KUO scheme proposed by Kuo (1974), and a prognostic Arakawa-Schubert scheme modified by Kuma (1996) (the PAS scheme). Although both cumulus convection schemes are widely used for the time-slice experiments (Sugi et al., 2002; Oouchi et al., 2006; Yoshimura et al., 2006), it is interesting to see which convection scheme is favorable to reproduce TC activity similar to actually observed.

10 Figure 2 shows the TC tracks calculated using the KUO and the PAS schemes together with the observed ones. We can see that the TC frequency for the KUO scheme is much less than that for the PAS scheme and/or actually observed. Furthermore, TCs for the KUO scheme do not propagate up northward compared to the others. These results indicate that the PAS scheme is favorable to examine summertime WNP wave 15 climate which strongly depends on TC activity. For this reason, we hereafter use only calculated results from time-slice experiments with the PAS scheme.

The atmospheric fields derived from the time-slice experiments are used to assess possible future changes of $\mathrm{SWH}$. We employ an empirical approach to project future changes of $\mathrm{SWH}$, where the difference of surface winds $\left(2 \times \mathrm{CO}_{2}\right.$ run minus control run) is incorporated into the linear regression model which will be introduced in Sect. 3.

\section{Results}

\subsection{Interannual variability of $\mathrm{H}_{90}$ in the WNP}

The spatial structure of the first EOF mode for $\mathrm{H}_{90}$ is characterized by a monopole structure with the maximum amplitude located to the south of Japan (Fig. 1a). Time variations of the $\mathrm{PC} 1$ for $\mathrm{H}_{90}$ (Fig. $1 \mathrm{~b}$ ) indicate that $\mathrm{H}_{90}$ increases during the ENSO years, namely, 1972, 1982, 1986, 1991, 1994, 1997, and 2002. This result is consistent

OSD

3, 1637-1651, 2006

\section{Wave height projection in the WNP}

W. Sasaki et al.

Title Page

Abstract Introduction

Conclusions References

Tables Figures

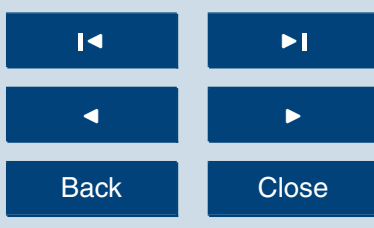

Full Screen / Esc

Printer-friendly Version

Interactive Discussion 
with Sasaki et al. (2005a) who showed that monthly mean SWH off the southern coast of Japan tends to increase during the ENSO years.

Typical atmospheric and oceanic anomalies associated with increase of $\mathrm{H}_{90}$ can be characterized by cyclonic circulation in the WNP in response to warm SST anomalies

5 in the Niño-3.4 region (Figs. 1c and d). Table 1a provides the decennial correlation coefficients between the SST averaged over the Niño-3.4 region (Niño-3.4 index) and the PC1 for $\mathrm{H}_{90}$ where we can see that the correlation between the Niño-3.4 index and the PC1 for $\mathrm{H}_{90}$ is low during 1960-1969 $(r=-0.16)$, but is much improved after 1970 $(r>0.5)$.

10 It is interesting to note that strong anomalous westerly winds can be found in the $\mathrm{SW}$ anomalies within the region $5^{\circ} \mathrm{N}-15^{\circ} \mathrm{N}, 130^{\circ} \mathrm{E}-160^{\circ} \mathrm{E}$. The time series of zonal wind anomalies averaged over this region $\left(\mathrm{U}_{10 \mathrm{~N}}\right)$ coincides with that of the PC1 for $\mathrm{H}_{90}$ (Fig. 1b). In fact, Table $1 \mathrm{~b}$ shows that $\mathrm{U}_{10 \mathrm{~N}}$ and the $\mathrm{PC} 1$ for $\mathrm{H}_{90}$ are positively correlated with each other after $1970(r>0.7)$, thus validating the linear regression model which 15 empirically predicts the $\mathrm{PC} 1$ for $\mathrm{H}_{90}$ in terms of $\mathrm{U}_{10 \mathrm{~N}}$. A dashed line in Fig. 3 shows a linear regression model which relates the $P C 1$ for $\mathrm{H}_{90}$ to $U_{10 \mathrm{~N}}$, where we can see the linear relationship between the $\mathrm{PC} 1$ for $\mathrm{H}_{90}$ and $\mathrm{U}_{10 \mathrm{~N}}$ based on the ERA-40 reanalysis. We can confirm the robust relationship between the $\mathrm{PC} 1$ for $\mathrm{H}_{90}$ and $\mathrm{U}_{10 \mathrm{~N}}$ based on the other datasets. A dotted line in Fig. 3 shows a linear regression model which relates the PC1 of $\mathrm{H}_{90}$ obtained from optimally interpolated TOPEX/Poseidon SWH to $U_{10 \mathrm{~N}}$ obtained from the National Centers for Environmental Prediction - National Center for Atmospheric Research (NCEP-NCAR) reanalysis for 1993-2004 (Sasaki and Hibiya, 2006). Correlation coefficient between the PC1 for $\mathrm{H}_{90}$ from the TOPEX/Poseidon $S W H$ and $U_{10 N}$ from the NCEP-NCAR reanalysis is 0.95 . Although small bias is found between the two regression models, their slopes are nearly identical. The robust relationship between the PC1 for $\mathrm{H}_{90}$ and $U_{10 \mathrm{~N}}$ thus confirmed enables us to use $\mathrm{U}_{10 \mathrm{~N}}$ as the predictor for the $\mathrm{PC} 1$ of $\mathrm{H}_{90}$.

The anomalous westerly winds may be associated with an eastward extension of the monsoon trough off the east of the Philippines, which brings about an eastward shift

OSD

3, 1637-1651, 2006

\section{Wave height projection in the WNP}

W. Sasaki et al.

Title Page

Abstract Introduction

Conclusions References

Tables Figures

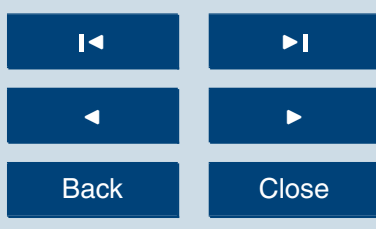

Full Screen / Esc

Printer-friendly Version

Interactive Discussion 
of the occurrence of TCs. In fact, the mean position of the occurrence of TCs during the highest seven years of the PC1 for $\mathrm{H}_{90}$ shifts southeastward when compared to that during the lowest seven years of the PC1 for $\mathrm{H}_{90}$ (Figures not shown), so that TCs may have longer duration until encountering the continent or cold mid-latitude water.

5 Wang and Chan (2002) showed that, during the strong ENSO events, TC tends to occur in the southeast quadrant $\left(0^{\circ} \mathrm{N}-17^{\circ} \mathrm{N}, 140^{\circ} \mathrm{E}-180^{\circ}\right)$ with the intensity increasing in proportion to its duration.

Table 1c shows that the $\mathrm{PC} 1$ for $\mathrm{H}_{90}$ is strongly correlated with the total duration of intense TC (ITC; TC with the central pressure below $980 \mathrm{hPa}$ ) computed from the 10 RSMC best-track data. This is consistent with Sasaki et al. (2005b) who showed that, in the WNP, summertime extreme ocean wave heights (defined as the June-August average of the highest $10 \%$ for a month) and total duration of ITC both increase since the late 1990s. In contrast, we cannot recognize any apparent correlation between the TC frequency and the PC1 for $\mathrm{H}_{90}$ (Table 1d). Poor correlations in the 1960s shown in 15 Table 1a-d may reflect a data problem of TC best-track data as well as the ERA-40, since the satellite monitoring of weather events in the WNP was not carried out before 1965.

\subsection{Projected changes of $\mathrm{H}_{90}$ in the WNP}

To conduct empirical projection of future changes of $\mathrm{H}_{90}$ in the WNP, we assume that 20 the statistical relationship between the $\mathrm{PC} 1$ for $\mathrm{H}_{90}$ and $\mathrm{U}_{10 \mathrm{~N}}$ at present-day will hold under the future climate condition. In the empirical approach, a 70-year change (from 1985-1995 to 2055-2065) of the 10-year mean of $\mathrm{H}_{90}$ is estimated using a linear regression model shown in Fig. 3. A pair of time-slice experiments shows that calculated $U_{10 \mathrm{~N}}$ at present-day is somewhat larger than actually observed, and increases 25 by $\sim 2 \mathrm{~ms}^{-1}$ under $\mathrm{CO}_{2}$-induced global warming condition (Fig. 3). Spatial pattern of the difference between SW fields obtained from the $2 \times \mathrm{CO}_{2}$ run and those obtained from the control run is characterized by cyclonic circulation in the WNP (Fig. 4), which resembles typical SW anomalies associated with the increase of $\mathrm{H}_{90}$ (Fig. 1d). Consid-

\section{OSD}

3, 1637-1651, 2006

\section{Wave height projection in the WNP}

W. Sasaki et al.

\section{Title Page}

Abstract Introduction

Conclusions References

Tables Figures

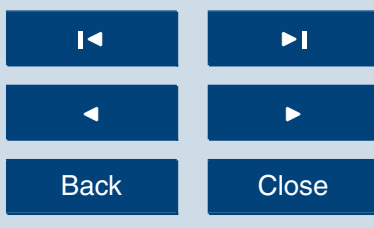

Full Screen / Esc

Printer-friendly Version

Interactive Discussion 
ering that future SST fields employed in the $2 \times \mathrm{CO}_{2}$ run exhibit ENSO-like features, enhancement of $U_{10 N}$ thus projected in the WNP is quite natural. Possible future changes of $\mathrm{H}_{90}$ can be estimated by incorporating the projected $\mathrm{U}_{10 \mathrm{~N}}$ into the regression model. We can see that the projected $\mathrm{H}_{90}$ increases by up to $\sim 0.4 \mathrm{~m}$ over a wide area of the 5 WNP (Fig. 4).

\section{Conclusions}

We have presented a 70-year change (from 1985-1995 to 2055-2065) of the 10-year mean of $\mathrm{H}_{90}$ in the western North Pacific under the GPS experiments in which $\mathrm{CO}_{2}$ concentration is assumed to increase at a rate following the IS92a scenario until 1990, 10 and at a rate $1 \%$ per year thereafter. For this purpose, we have conducted $10-y r$ timeslice experiments using T106 AGCM. Future projection has been carried out through an empirical approach using the possible atmospheric fields derived from the timeslice experiments. It has been projected that $\mathrm{H}_{90}$ increases by up to $\sim 0.4 \mathrm{~m}$ over a wide area of the western North Pacific.

\section{References}

Bauer, E. and Staabs, C.: Statistical properties of global significant wave heights and their use for validation, J. Geophys. Res., 103(C1), 1153-1166, 1998.

Delworth, T. L., Stouffer, R. J., Dixon, K. W., Spelman, M. J., Knutson, T. R., Broccoli, A. J., Knushner, P. J., and Wetherald, R. T.: Review of simulations of climate variability and change 20 with GFDL R30 coupled climate model, Clim. Dyn., 19, 555-574, 2002.

lizuka, S., Orito, K., Matsuura, T., and Chiba, M.: Influence of cumulus convection schemes on the ENSO-like phenomena simulated in a CGCM, J. Meteorol. Soc. Japan, 81, 85-827, 2003.

Krishnamurti, T. N., Correa-Torres, R., Latif, M., and Daughenbaugh, G.: The impact of current and possibly future SST anomalies on the frequency of Atlantic hurricanes, Tellus, 50A, 186210, 1998.

\section{OSD}

3, 1637-1651, 2006

\section{Wave height projection in the WNP}

W. Sasaki et al.

\section{Title Page}

\section{Abstract}

Introduction

Conclusions

References

Tables

Figures

I

4

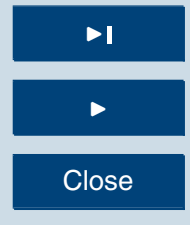

Back

Full Screen / Esc

Printer-friendly Version

Interactive Discussion 
Kuma, K.: Parameterization of cumulus convection, JMA/NPD Report No. 42, 93pp, 1996.

Kuo, H. L.: Further studies of the influence of cumulus convection on large scale flow, J. Atmos. Sci., 31, 1232-1240.

Matsuura, T., Yumoto, M., lizuka, S., Kawamura, R.: Typhoon and ENSO simula5 tion using a high-resolution coupled GCM, Geophys. Res. Lett., 26(12), 1755-1758, doi:10.1029/1999GL900329, 1999.

Oouchi, K., Yoshimura, J., Yoshimura, H., Mizuta, R., Kusunoki, S., and Noda, A.: Tropical cyclone climatology in a global-warming climate as simulated in a $20 \mathrm{~km}-\mathrm{mesh}$ global atmospheric model: frequency and wind intensity analyses, J. Meteorol. Soc. Japan, 84, 259-276, 102006

Sasaki, W., Iwasaki, S. I., Matsuura, T., lizuka, S., and Watabe, I.: Changes in wave climate off Hiratsuka, Japan, as affected by storm activity over the western North Pacific, J. Geophys. Res., 110, C09008, doi:10.1029/2004JC002730, 2005a.

Sasaki, W., Iwasaki, S. I., Matsuura, T., and lizuka, S.: Recent increase in summertime 15 extreme wave heights in the western North Pacific, Geophys. Res. Lett., 32, L15607, doi:10.1029/2005GL023722, 2005b.

Sasaki, W. and Hibiya, T.: Interannual variability and predictability of summertime significant wave heights in the western North Pacific, J. Oceanogr., in press, 2006.

Smith, T. M. and Reynolds, R. W.: Improved extended reconstruction of SST (1854-1997), J. Clim., 17, 2466-2477, 2004.

Sugi, M., Kuma, K., Tada, K., Tamiya, K., Hasegawa, N., Iwasaki, T., Yamada, S., and Kitade, T.: Description and performance of the JMA operational global spectral model (JMA-GSM88), Geophys. Mag., 43, 105-130, 1990.

Sugi, M., Noda, A., and Sato, N.: Influence of the global warming on tropical cyclone climatology: An experiment with the JMA global model, J. Meteorol. Soc. Japan, 80, 249-272, 2002.

Tolman, H. L.: User manual and system documentation of WAVEWATCH-III version 1.18, NOAA/NWS/NCEP Ocean Modeling Branch Contribution 166, 112pp, 1999.

Wang, B. and Chan, J. C. L.: How strong ENSO events affect tropical storm activity over the western North Pacific, J. Clim., 15, 1643-1658, 2002.

Wang, X. L., Zwiers, F. W., and Swail, V. R.: North Atlantic ocean wave climate change scenarios for the twenty-first century, J. Clim., 17, 2368-2383, 2004.

Wang, X. L. and Swail, V. R.: Climate change signal and uncertainty in projections of ocean

\section{Wave height projection in the WNP}

W. Sasaki et al.

\section{Title Page}

Abstract Introduction

Conclusions References

Tables Figures

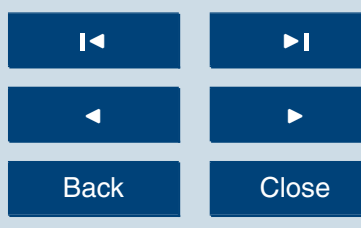

Full Screen / Esc

Printer-friendly Version

Interactive Discussion 
wave heights, Clim. Dyn., 26, 109-126, doi:10.1007/s00382-005-0080-x, 2006.

WASA Group: Changing waves and storms in the northeast Atlantic?, Bull. Amer. Meteorol. Soc., 79, 741-760, 1998.

Yoshimura, J., Sugi, M., and Noda, A.: Influence of greenhouse warming on tropical cyclone 5 frequency, J. Meteorol. Soc. Japan, 84, 405-428, 2006.
OSD

3, 1637-1651, 2006

\section{Wave height projection in the WNP}

W. Sasaki et al.

Title Page

\section{Abstract}

Introduction

Conclusions

References

Tables

Figures

14

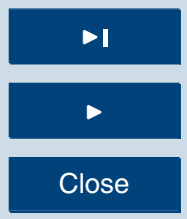

Back

Full Screen / Esc

Printer-friendly Version

Interactive Discussion 
OSD

3, 1637-1651, 2006

\section{Wave height projection in the WNP}

W. Sasaki et al.

Table 1. Decennial correlation coefficients between the $\mathrm{PC} 1$ for $\mathrm{H}_{90}$ in the western North Pacific and (a) the Niño-3.4 index, (b) $\cup_{10 N}$, (c) total duration of ITC, and (d) TC frequency.

\begin{tabular}{rrrrrr}
\hline \multicolumn{5}{c}{ Period } \\
\hline & $1960-1969$ & $1970-1979$ & $1980-1989$ & $1990-2002$ & $1960-2002$ \\
\hline (a) & -0.16 & 0.60 & 0.67 & 0.56 & 0.49 \\
(b) & 0.00 & 0.88 & 0.77 & 0.83 & 0.66 \\
(c) & 0.22 & 0.68 & 0.81 & 0.81 & 0.63 \\
(d) & 0.21 & 0.44 & -0.14 & 0.38 & 0.02 \\
\hline
\end{tabular}

\section{Title Page}

\section{Abstract}

Introduction

Conclusions

References

Tables

Figures

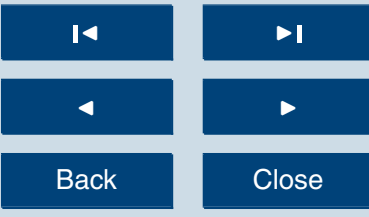

Full Screen / Esc

Printer-friendly Version

Interactive Discussion 
(a)

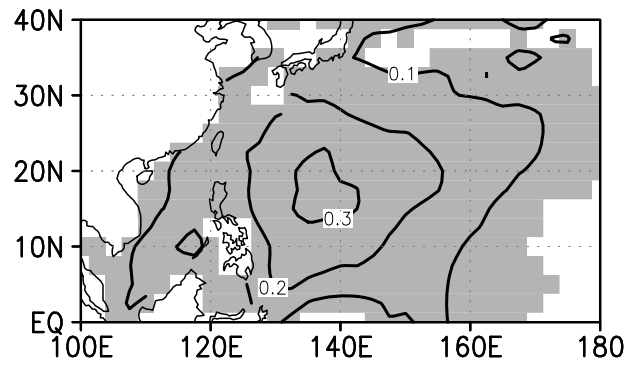

(c)

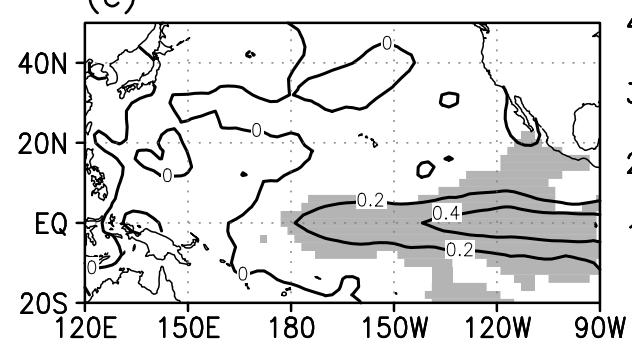

1960

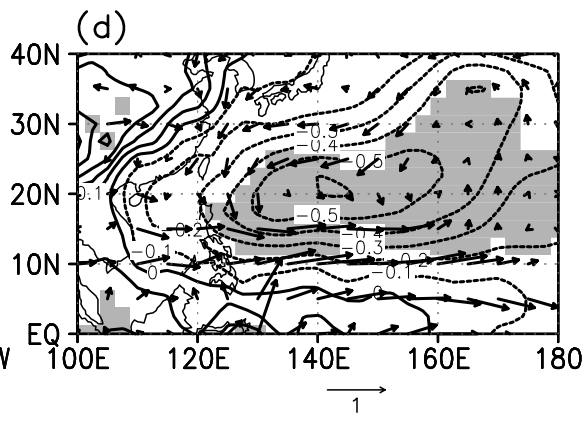

Fig. 1. (a) A map showing the linear regression coefficients between $\mathrm{H}_{90}$ and the $P C 1$ for $\mathrm{H}_{90}$. Unit is $\mathrm{m}$. Shaded region indicates the correlation is significant at the $1 \%$ level. (b) Time series of the PC1 for $\mathrm{H}_{90}$ (solid line) and $U_{10 \mathrm{~N}}$ (dotted line). Both are normalized. (c) A map showing the linear regression coefficients between SST and the PC1 for $\mathrm{H}_{90}$. Unit is degC. Shaded region indicates the correlation is significant at the $1 \%$ level. (d) A map showing the linear regression coefficients between the PC1 for $\mathrm{H}_{90}$ and each of SLP (contour) and SW (arrow). Unit of SLP is $\mathrm{hPa}$. Shaded region indicates the correlation with SLP is significant at the $1 \%$ level.

\section{OSD}

3, 1637-1651, 2006

\section{Wave height projection in the WNP}

W. Sasaki et al.

Title Page

Abstract

Introduction

Conclusions

References

Tables

Figures

14

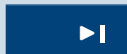

4

Back

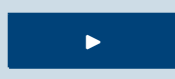

Close

Full Screen / Esc

Printer-friendly Version

Interactive Discussion 


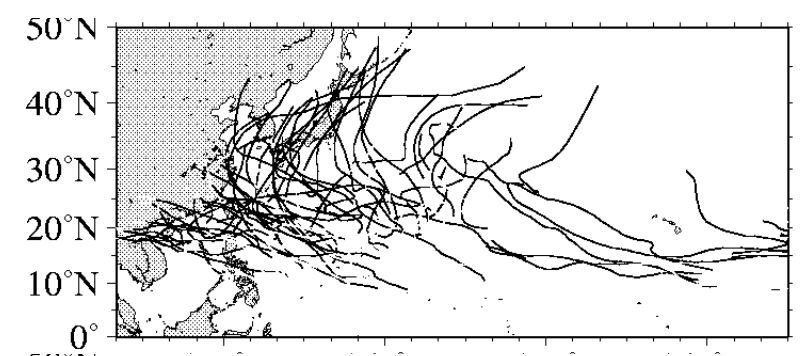

OSD

\section{3, 1637-1651, 2006}

\section{Wave height projection in the WNP}

W. Sasaki et al.

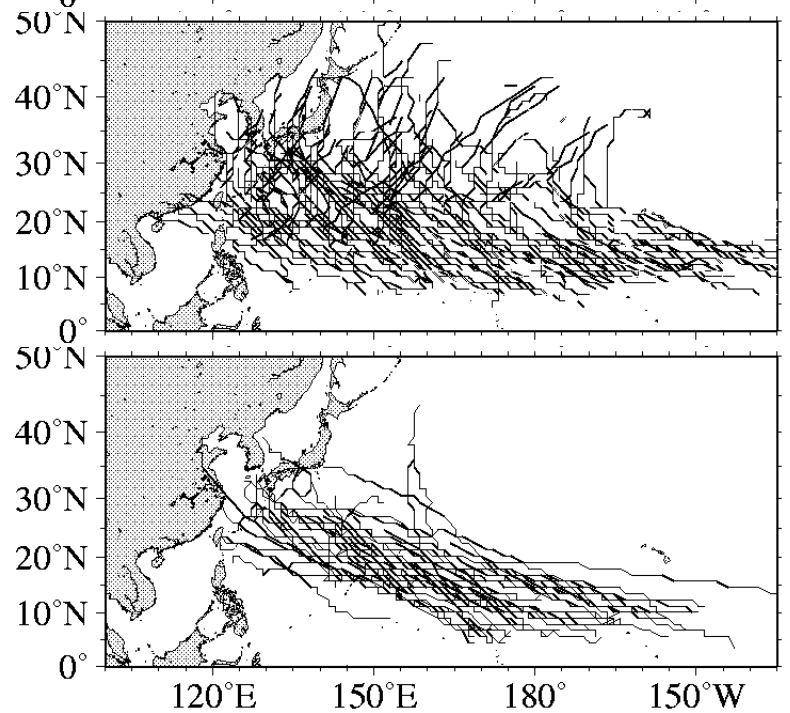

Title Page

Abstract

Introduction

Conclusions

References

Tables

Figures

14

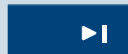

4

4

Back

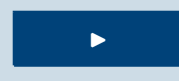

Full Screen / Esc

Printer-friendly Version

Interactive Discussion

EGU 


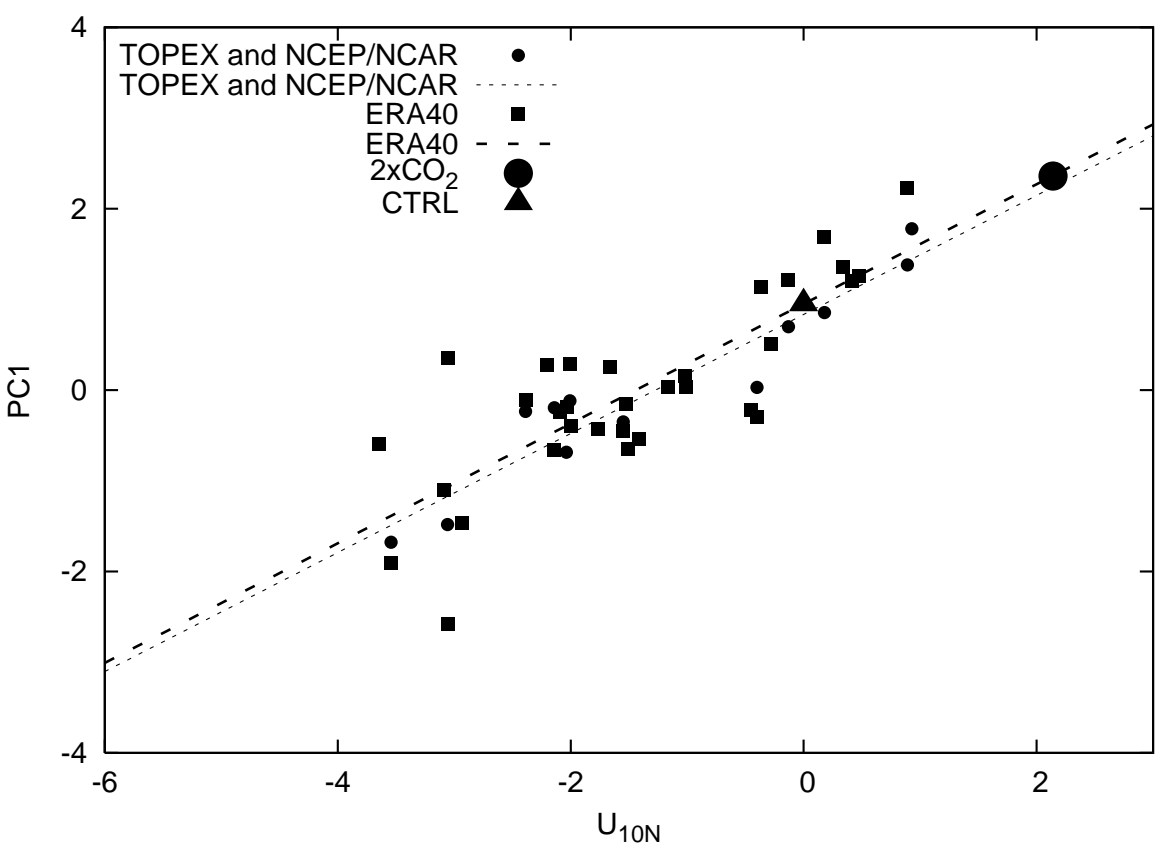

Fig. 3. Relationship between the PC1 for $\mathrm{H}_{90}$ in the western North Pacific and $\mathrm{U}_{10 \mathrm{~N}}$ obtained from the ERA-40 reanalysis (square) as well as from the TOPEX/Poseidon and the NCEPNCAR reanalysis (circle). Our regression model is represented by a straight line obtained from the least square fit. The dashed line is for the ERA-40 reanalysis, whereas the dotted line is for the TOPEX/Poseidon and the NCEP-NCAR reanalysis. The triangle shows the PC1 for $\mathrm{H}_{90}$ projected by $\mathrm{U}_{10 \mathrm{~N}}$ derived from the control run, whereas the large circle shows the PC1 for $\mathrm{H}_{90}$ projected by $\mathrm{U}_{10 \mathrm{~N}}$ derived from the $2 \times \mathrm{CO}_{2}$ run (both projections are carried out using the regression model based on the ERA-40 reanalysis).

\section{OSD}

3, 1637-1651, 2006

\section{Wave height projection in the WNP}

W. Sasaki et al.

Title Page

\section{Abstract}

Introduction

Conclusions

References

Tables

Figures

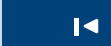

-I

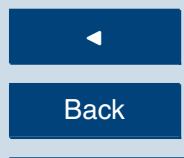

一

Close

Full Screen / Esc

Printer-friendly Version

Interactive Discussion 
OSD

3, 1637-1651, 2006

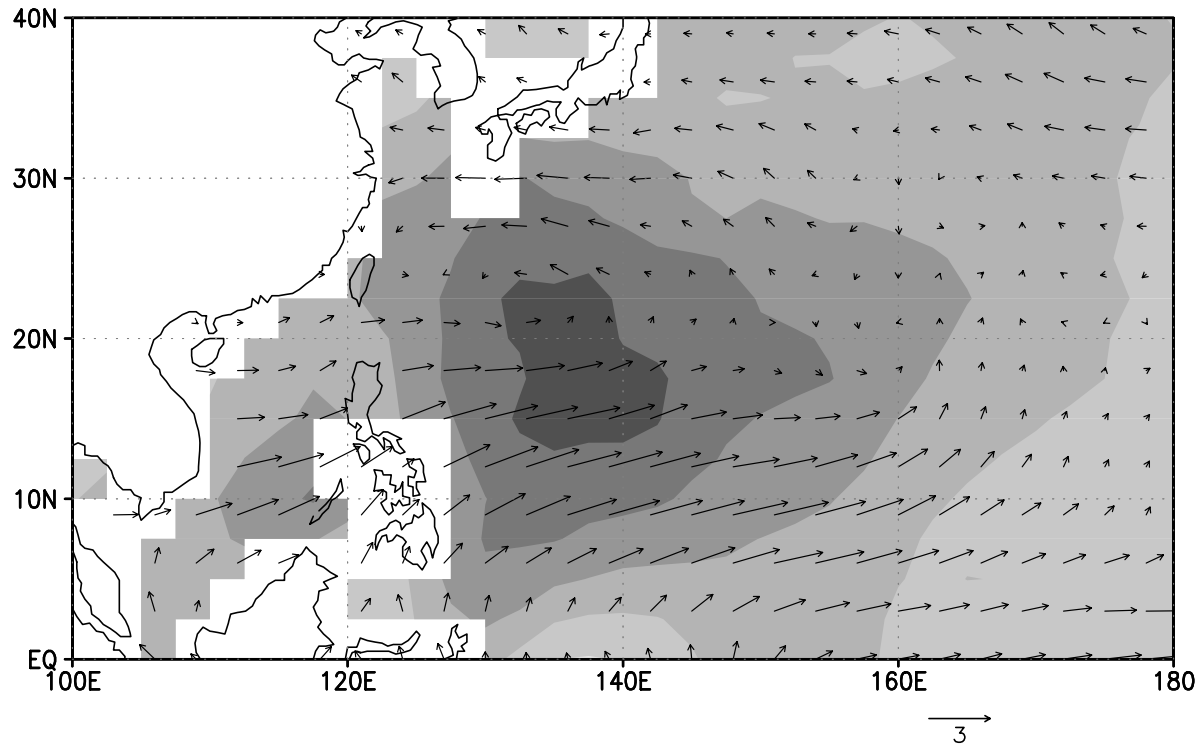

Fig. 4. A projected 70-year change (2055-2065 minus 1985-1995) of the 10-year mean of $\mathrm{H}_{90}$. Unit is $\mathrm{m}$. Arrow shows the difference between surface wind vector obtained from the $2 \times \mathrm{CO}_{2}$ run and that obtained from the control run. Unit of wind speed is $\mathrm{ms}^{-1}$.

\section{Wave height projection in the WNP}

W. Sasaki et al.

Title Page

\section{Abstract}

Introduction

Conclusions

References

Tables

Figures

14

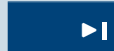

4

Back

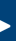

Close

Full Screen / Esc

Printer-friendly Version

Interactive Discussion 